\title{
The Transparency of Public Service in Pelalawan District
}

\author{
Syaprianto \\ University Islamic of Riau \\ Pekanbaru, Indonesia \\ E-mail: Syaprianto@soc.uir.ac.id
}

\begin{abstract}
Government as a public service provider, is in fact the service given to the community often unsatisfied in Pelalawan District. One of them is by realizing the transparency of publics service seriously by providing certainty of requirement, cost and time. Thus the public's trust in the government will be better. The theoretical approach that the writers use from various theories is the fact that it is important in the solving the problems faced in realizing the transparency of public services because so far transparency in public services as not been realized maximally, so that it is needed strategy to realize transparency in giving service.
\end{abstract}

\section{Keyword: Transparency, Public Service, Local Government.}

\section{INTRODUCTION}

To achieve the successful implementation of regional autonomy in Pelalawan district is determined by the performance of local governments in implementing public services, because the community will directly assess the good or bad public services provided. The law expressly states that the implementation of local government, which regulates and administers its own governmental affairs according to the principle of autonomy, aims to realize the welfare of the community one of them through the improvement of public services.

Today the concept of good governance is a necessity and transparency is one of the principles of good governance it self. Good governance and regional autonomy are two interrelated concepts, interconnected and mutually cooperative. Both of them provide a conducive atmosphere so that the creation of a public service as expected. However, the concept of good governance in its implementation is not as easy as imagined, but it needs hard work in realizing it because in it there are elements of ethics or values. So the government issued a policy related to the development of transparency in public services. The government policy to develop the transparency of public services is regulated in the Decree of the Minister of Administrative Reforms Number.

KEP /26 / M.PAN / 2/2004 Concerning Technical Guidelines for Transparency and Accountability in Public Service Delivery. This policy of course refers to the 1945 Constitution has mandated that the state is obliged to serve every citizen in order to fulfill his basic needs one of them through public services to improve the welfare of the community.

The implementation of public services carried out by the Pelalawan district government has not been able to satisfy the public especially concerning the fulfillment of civil rights and basic needs of the community such as the identity card management service, the lack of public services in Pelalawan district so far, among others, due to not yet implemented transparency in the implementation of public services as a whole. Therefore, transparency in public services must be implemented by the government.

\section{PROBLEM FORMULATION}

Given the importance of the issue of transparency in public services, the formulation of the problem "How is transparency of public services in Pelalawan district?"

\section{DISCUSSION}

\section{A. Basic Concepts of Public Service}

Public services can be traced through the term civil service. The term civil comes from the Latin civil (adjective), ie everything that concerns the daily life of citizens outside military affairs and worship. Civil service may be distinguished into civil service to fulfill human rights and civil services to fulfill derivative rights, or rights as a legal consequence concerning a person. For example, must ask for permission if someone wants to open a business.

The civil service providers mentioned above are bureaucracy. Therefore, the civil service can also be called bureaucratic or public service. Thus, bureaucratic services or public services are included in civil services. Considering the bureaucratic product is service, bureaucracy is a government service factory. Menpan. 63 Year 2003 states that the nature of public service is the provision of excellent service to the community which is the obligation of the government apparatus Decree, to be able to provide satisfactory service for service users, the service should meet the following principles of service:

1. Transparent

2. Accountability

3. Conditional

4. Participatory

5. Equal rights 
6. Balance of rights and obligations

1. Simplicity

The principles of public service are:

2. Clarity

3. Certainty of time

4. Accuracy

5. Security

6. Responsibility

7. Feasibility of facilities and infrastructure

8. Ease of access

9. Discipline, courtesy, and hospitality

10. Convenience

\section{B. Transparency in the Delivery of Public Services}

Transparency in the context of the delivery of public services is open, easy, and accessible to all those in need and provided adequately and easily understood (Ratminto, Winarsih, 2005: 19). Public service is any service activities undertaken by public service providers as an effort to meet the needs of recipients of service needs and implementation of the provisions of legislation (Ratminto and Winarsih, 2005: 18).

So conceptually, transparency in the implementation of the public is any service activities undertaken by public service providers as an effort to meet the needs of service recipients and the implementation of the provisions of legislation, which is open, easy, and accessible to all parties in need and provided adequately and easily understood by all recipients of service needs.

Transparency of public service delivery is the implementation of tasks and activities that are open to the public from the policy process, planning, implementation, and supervision / control, and easily accessible to all parties who need information. Transparency is built in an atmosphere of free information flow.

In this atmosphere, processes, institutions, and information can be directly accessed by those concerned. In addition, there is also enough information to understand and monitor these three things (Hamdi, 2001: 52-51). According to Riswandha (2003: 59), transparency is the people understand the overall decision-making process undertaken by the government.

Thus, transparency means being open, easy, and accessible to all those in need and provided adequately and easily understood.Transparency requires that the public service provider be knowledgeable about the issues and information relevant to the service activities.

According to Ratminto and Winarsih (2005: 209-216), at least 10 (ten) dimensions or actual conditions are expected to occur in the transparency of public service delivery, namely:

1. The management and implementation of public services should be informed and accessible to the public.

2. The service procedure shall be made in the form of a Chart.

3. The technical and administrative requirements of the service should be clearly informed to the public.
4. Certainty of details of service costs should be clearly informed to the public.

5. Certainty and period of completion of service must be clearly informed to the public.

6. The authorized officers and officers responsible for providing services shall be formally established on the basis of a decree.

7. problems / disputes, required to wear identification and signage on the desk / workplace officer.

8. The location of service should be clear.

9. Promise of service should be clearly written.

10. Public service standards should be realistic and publicized.

11. Service Information should be published and socialized to the public through the media.

\section{CONCLUSION}

Implementation of transparency in public administration in Pelalawan district is an effort to fulfill the needs of service recipients in accordance with laws and regulations, which are open, easy, and accessible to those in need and provided adequately and easily understood by all beneficiaries of public services. Thus, to achieve this, actual conditions such as: management and delivery of public services should be publicized and easily accessible to the public as well as service procedures should be made by eg in the form of a chart, as well as the technical and administrative requirements of the service should be clearly publicized, the certainty of the details of the cost of services should be clearly publicized, the certainty of the time in the completion of the service should be clearly publicized, and all information related to the service should be published and also socialized. In addition, a number of supporting factors also need to be considered such as policies made by the government to support or not, the availability of facilities and infrastructure that support, and the ability of employees and not less important is the awareness of citizens, employee commitment, supervision and sanctions, work culture, and patterns the right service.

\section{REFERENCES}

[1] Hamdi, Muchlis, "Good Governance dan Kebijakan Otonomi Daerah." Jurnal Otonomi Daerah, Vol. I (2), Oktober 2001, hal. 52-54, 2001

[2] Kantor Kementerian PAN RI. 2004. Keputusan Menteri Pendayagunaan Aparatur Negara Nomor. KEP/26/M.PAN/2/2004 Tentang Petunjuk Teknis Transparansi dan Akuntabilitas Dalam Penyelenggaraan Pelayanan Publik, 2004

[3] Republik Indonesia, Instruksi Presiden Nomor 1 Tahun 1995 Tentang Perbaikan dan Peningkatan Mutu Pelayanan Aparatur Pemerintah Kepada Masyarakat,1995

[4] -----------, Instruksi Presiden Republik Indonesia Nomor 5 Tahun 2003Tentang Paket Kebijakan Ekonomi, 2003

[5] ------------, Undang-undang Nomor 32 Tahun 2004 Tentang Pemerintahan Daerah, 2004

[6] Ratminto dan Atik Septi Winarsih, Manajemen Pelayanan : Pengembangan Model Konseptual, Penerapan Citizen's Charter, dan Standar Pelayanan Minimal. Yogyakarta: Pustaka Pelajar, 2005

[7] Riswandha Imawan, "Desentralisasi, Demokratisasi, dan Pembentukan Good Governance.” Jurnal Otonomi Daerah, Vol. II (6), Juni 2003, hal. 56-60. Sjahrir. 2002. Good Governance : Tinjauan Kritis. Jakarta: LAN RI, 2003 
[8] Taliziduhu Ndhara. 2000. Ilmu Pemerintahan I. Jakarta: BKU IIP. United Nation Development Program (UNDP), Tahap Pertama Memajukan Pemerintahan yang Baik dan Transparansi yang Sah. Terjemahan Purwinta. Yogyakarta : UNDP dan FISIP UGM Yogyakarta, 2000. 